Edyta Dotegowska

Uniwersytet w Biatymstoku

\title{
OGRANICZANIE WŁASNOŚCI ZE WZGLĘDU NA OCHRONĘ ŚRODOWISKA W KONTEKŚCIE ZASADY ZRÓWNOWAŻONEGO ROZWOJU
}

„Dla istnienia ludzkości własność musi ustapić przed wymogami ochrony środowiska."

\section{Wprowadzenie}

Celem niniejszego artykułu jest analiza problematyki ograniczania własności ze względu na ochronę środowiska w kontekście zasady zrównoważonego rozwoju. W konsekwencji to także próba odpowiedzi na pytanie, w jaki sposób zachować niezbędną równowagę pomiędzy interesem publicznym i prywatnym w zakresie ograniczania prawa własności ze względu na ochronę środowiska. Konieczność utrzymania tej równowagi wynika z konstytucyjnej zasady zrównoważonego rozwoju, wyrażonej w art. 5 Konstytucji Rzeczypospolitej Polskiej. B. Rakoczy określa tę zasadę jako pewne założenie ustawodawcy, że ochronie prawnej podlegają dwie równorzędne wartości, a zadaniem władz publicznych jest znalezienie złotego środka współistnienia tych wartości. ${ }^{2}$ Zasada zrównoważonego rozwoju bowiem w samej swej istocie zakłada pewien konflikt pomiędzy dwiema wartościami, którym należy przypisać rangę konstytucyjną - prawem własności i ochroną środowiska. Na styku tych dwóch wartości znajdują się prawa i wolności jednostki, mającej $\mathrm{z}$ jednej strony podmiotowe prawo własności, z drugiej zaś zobowiązanej do dbałości o otaczające ją środowisko. Istotą zrównoważonego rozwoju w tym kontekście będzie więc zachowanie prawidłowej równowagi oraz - w oparciu o wykładnię wynikającej z niego zasady - rozwiązywanie konfliktów pomiędzy dwiema wartościami konstytucyjnymi - prawem własności i ochroną środowiska. W przedmiotowej materii, jak trafnie zauważył J. Sommer, po jednej stronie stoi konieczność

Za: J. Sommer, Ochrona środowiska a prawo własności, Wrocław 2000, s. 8.

2 B. Rakoczy, Ograniczenie praw i wolności jednostki ze względu na ochronę środowiska w Konstytucji Rzeczpospolitej Polskiej, Toruń 2006, s. 150. 
ochrony własności jako podstawy gospodarki rynkowej, z drugiej zaś konieczność ochrony środowiska wynikająca z zasady zrównoważonego rozwoju.

\section{Pojęcie „zrównoważony rozwój”}

Zasada zrównoważonego rozwoju stanowi regułę konstytucyjną, ujętą w art. 5 Konstytucji Rzeczypospolitej Polskiej. ${ }^{3}$ Współcześnie uznawana jest za najistotniejszą zasadę współczesnego prawa ochrony środowiska. Należy jednak wyraźnie podkreślić, że nie jest ona właściwa tylko dla tej gałęzi prawa, bowiem swoim zakresem obejmuje zdecydowanie szersze obszary regulacji prawnych, jak i pozaprawnych, zarówno tych wymienionych w art. 5 Konstytucji, jak i niesformułowanych w nim expressis verbis. Zdaniem B. Rakoczego, niedopuszczalne jest ograniczanie zrównoważonego rozwoju jedynie do problematyki ochrony środowiska, choć tendencja polskiej legislacji w tym zakresie wskazuje na redukcję przedmiotowej zasady właśnie do aspektów stricte prawno-środowiskowych. ${ }^{4}$

Zgodnie z art. 5 Konstytucji RP, „Rzeczypospolita Polska strzeże niepodległości i nienaruszalności swojego terytorium, zapewnia wolności i prawa człowieka i obywatela oraz bezpieczeństwo obywateli, strzeże dziedzictwa narodowego oraz zapewnia ochronę środowiska, kierując się zasadą zrównoważonego rozwoju". ${ }^{5}$

Zasadę zrównoważonego rozwoju postrzegać należy w kontekście wykładni obowiązków, jakie nałożone są na Rzeczypospolitą Polską, czyli na władze publiczne. To właśnie one winny kierować się zasadą zrównoważonego rozwoju w wykonywaniu zadań określonych w przedmiotowym art. 5 Konstytucji, zarówno w zakresie stanowienia, jak i stosowania prawa. $Z$ zasady tej wynikają także obowiązki dla innych podmiotów, w szczególności zaś w odniesieniu do praw i wolności jednostki, co ma bezpośredni wpływ na jej sytuację prawną. ${ }^{6}$

W Konstytucji Rzeczypospolitej Polskiej brak jest definicji normatywnej zrównoważonego rozwoju. Inne regulacje konstytucyjne odnoszące się do ochrony środowiska także nie wskazują zakresu treściowego przedmiotowej reguły. Pojęcie to zostaje jednak dookreślone w aktach rangi ustawowej. Według art. 3 pkt 50 ustawy z dnia 27 kwietnia $2001 \mathrm{r}$. Prawo ochrony środowiska ${ }^{7}$ rozwój zrównoważony to taki rozwój społeczno-gospodarczy, w którym następuje proces integrowania działań politycznych, gospodarczych i społecznych, z zachowaniem równowagi przyrodniczej oraz trwałości podstawowych procesów przyrodniczych, w celu zagwarantowania możliwości zaspokajania podstawowych potrzeb poszczególnych społeczności lub obywateli zarówno współczesnego pokolenia, jak i przyszłych pokoleń. Należy za-

Ustawa z dnia 2 kwietnia 1997 r. Konstytucja Rzeczypospolitej Polskiej (Dz.U z 1997 r. Nr 78, poz. 483 ze zm.)

B. Rakoczy, Ograniczenie..., op. cit., s. 150.

Ibidem, s. 150.

Ibidem, s. 151.

Ustawa z dnia 27 kwietnia 2001 r. Prawo ochrony środowiska (Dz.U. z 2001 r. Nr 62, poz. 627 ze zm.). 
uważyć, że z samej treści tej definicji wynika, iż odnosi się ona wyłącznie do kwestii ochrony środowiska. Istotą tej zasady jest bowiem zachowanie równowagi pomiędzy ochroną środowiska a trzema rodzajami procesów: gospodarczym, społecznym i politycznym. W ocenie B. Rakoczego, najwłaściwsza jest taka postawa, która generalnie dopuszcza postęp i rozwój gospodarczy, społeczny i polityczny, jednocześnie nakazując prowadzić go w takim kierunku, aby uwzględnić wymogi wynikające $\mathrm{z}$ ochrony środowiska. ${ }^{8} \mathrm{~W}$ świetle powyższych uwag z poglądem tym należy się w pełni zgodzić.

Pojęcie zasada zrównoważonego rozwoju jest również przedmiotem szerokiej dyskusji w doktrynie nauk prawnych i pozaprawnych. Niejednokrotnie pojawiają się wątpliwości co do charakteru zasady zrównoważonego rozwoju, jej znaczenia i treści. ${ }^{9}$ M. Bar i J. Jendrośka, jak również Z. Bukowski uznają ją za zasadę ustrojową. ${ }^{10}$ W ocenie zaś W. Wołpiuka, zrównoważony rozwój jest pojęciem pozaprawnym, o charakterze ekonomicznym. R. Paczuski podkreśla dwoistość tej zasady, z jednej strony jako podstawowej reguły prawnej, z drugiej zaś jako pierwszej zasady polityki państwa. ${ }^{11}$

Jak podnosi R. Paczuski, zrównoważony rozwój z zapewnieniem ochrony środowiska zyskał rangę podstawowego zadania państwa i ustrojowej zasady Rzeczpospolitej Polskiej. ${ }^{12}$

Funkcjonowanie zasady zrównoważonego rozwoju w kontekście ograniczenia prawa własności ze względu na ochronę środowiska wyraża się poprzez realizację potrzeb społeczeństwa rozumianego globalnie. Jak trafnie podnosi B. Rakoczy, nie jest bowiem możliwe realizowanie zadań zrównoważonego rozwoju, jeśli akcent położony jest na wymiar indywidualny, a dopiero w następnej kolejności na aspekt ogólnoludzki. Dopiero przemiany ogólnospołeczne prowadzą do zmian w wymiarze indywidualnym. ${ }^{13}$

\section{Pojęcie własności}

Ochrona własności jest jednym z podstawowych zagadnień odnoszącym się do praw człowieka. Art. 1 Protokołu nr 1 do Europejskiej Konwencji Praw Człowieka stanowi, że każda osoba fizyczna i prawna ma prawo do poszanowania swojego mienia. Nikt nie może być pozbawiony swojej własności, chyba że w interesie

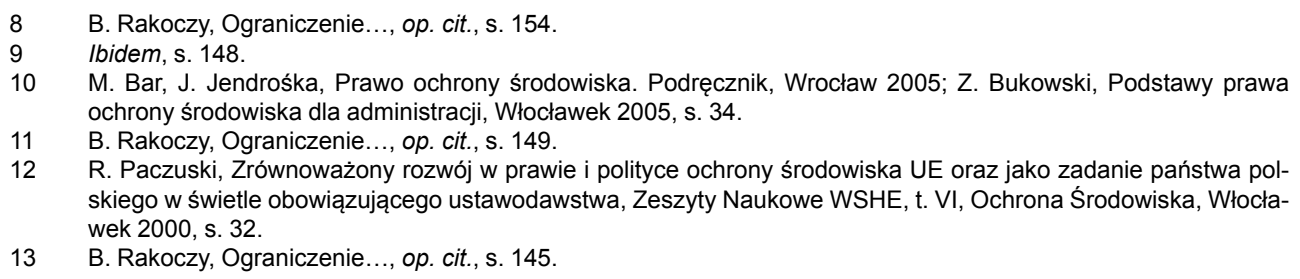

12 R. Paczuski, Zrównoważony rozwój w prawie i polityce ochrony środowiska UE oraz jako zadanie państwa polskiego w świetle obowiązującego ustawodawstwa, Zeszyty Naukowe WSHE, t. VI, Ochrona Środowiska, Włocławek 2000, s. 32.

13 B. Rakoczy, Ograniczenie..., op. cit., s. 145. 
publicznym i na warunkach przewidzianych w ustawie oraz zgodnie z ogólnymi zasadami prawa międzynarodowego. W odniesieniu do ochrony własności wynikającej z EKPCZ, wyróżnić można następujące kategorie zasad: zasadę poszanowania mienia, zasadę dopuszczalności pozbawienia prawa własności oraz zasadę dozwolonego wprowadzania przez państwo kontroli korzystania z własności. ${ }^{14}$

$\mathrm{W}$ celu prawidłowej analizy ograniczeń prawa własności, rozważania w tym zakresie należy zacząć od samego pojęcia własności. Jest ona rozumiana z jednej strony jako podstawowe prawo podmiotowe jednostki, z drugiej zaś jako naczelny warunek prawidłowo funkcjonującej gospodarki, której system określa się jako rynkowy. Oba te ujęcia znajdują swoje odzwierciedlenie w zapisach Konstytucji RP, która podnosi ochronę własności do rangi zasady ustrojowej.

Ochrona własności jest jednym z podstawowych zadań państwa, wyrażonym w art. 21 Konstytucji RP, który przewiduje, że „Rzeczpospolita Polska chroni własność i prawo dziedziczenia". Ta generalna ochrona, do której zobligowana jest władza publiczna, jest niezależna od przyznania jednostce uprawnień o charakterze indywidualnym. To fundamentalna zasada, która ze względu na ujęcie jej w rozdziale pierwszym Konstytucji, powinna stanowić pewne odniesienie w przypadku interpretacji innych regulacji dotyczących prawa własności.

Po drugie, Konstytucja RP gwarantuje prawo do własności, nadając mu rangę prawa podmiotowego, poprzez umieszczenie go w rozdziale II Konstytucji: „Wolności, prawa i obowiązki człowieka i obywatela". Zgodnie bowiem z art. 64 Konstytucji, każdy ma prawo do własności, innych praw majątkowych oraz prawo dziedziczenia, a prawa te podlegają równej dla wszystkich ochronie prawnej. Ponadto własność może być ograniczona tylko w drodze ustawy i tylko w zakresie, w jakim nie narusza ona istoty prawa własności. Za naruszenie istoty własności uznaje się takie ograniczenie własności, które godzi w podstawowe uprawnienia właścicielskie w taki sposób, że uniemożliwia to korzystanie z rzeczy i rozporządzanie nią ${ }^{15}$ Istotę prawa własności należy rozumieć więc w kontekście ustanowienia pewnych nieprzekraczalnych granic, stanowiących minimum uprawnień właścicielskich. W ocenie T. Dybowskiego nie można jednak uznać, że wszelkie ograniczenia ustawowe są dopuszczalne, ponieważ wyznaczają granice własności. Przepisy ustawowe nie mogą bowiem wyłączać podstawowych uprawnień składających się na treść prawa własności, takich jak możliwość korzystania, pobierania pożytków czy bezpośredniego lub pośredniego eksploatowania przedmiotu własności. ${ }^{16}$

Kolejnym konstytucyjnym ujęciem prawa własności jest art. 20 Konstytucji, który uznaje prawo własności jako konieczny element społecznej gospodarki rynko-

14 I. Nakielska, Prawo do własności w świetle Europejskiej Konwencji Praw Człowieka, Gdańsk 2002, s. 119.

15 S. Rudnicki, Komentarz do kodeksu cywilnego, księga druga: Własność i inne prawa rzeczowe, Warszawa 2005, s. 32 .

16 T. Dybowski, Własność w przepisach konstytucyjnych wedle stanu obowiązywania w 1996 r., (w:) Konstytucja i gwarancje jej przestrzegania, Księga pamiątkowa ku czci Prof. Janiny Zakrzewskiej, Warszawa 1996, s. 321. 
wej. Na marginesie należy zwrócić uwagę na fakt, iż prawo własności przysługujące jednostkom samorządu terytorialnego ma również swoje źródło w konstytucyjnych regulacjach dotyczących własności, mianowicie w art. 165 ust. 1 ustawy zasadniczej.

W odniesieniu do przywołanych wyżej regulacji, w doktrynie wykształciły się dwa odrębne znaczenia własności. Termin ten występuje jako synonim mienia w art. 20 i 21 Konstytucji oraz jako składnik mienia - prawo własności, rozumiane jako jedno z podmiotowych praw majątkowych - art. 64 i 165 Konstytucji. ${ }^{17}$ Orzecznictwo Trybunału Konstytucyjnego już na początku obowiązywania obecnej Konstytucji RP pozwoliło wykształcić jednolitą interpretację tych dwóch ujęć własności. W ocenie Trybunału, zagwarantowanie ochrony własności wynikające z art. 21 ustawy zasadniczej jest konstytucyjną powinnością państwa, przy czym powinność ta urzeczywistniana jest zarówno przez działania o charakterze prawodawczym, rozumiane jako ukształtowanie podstawowych instytucji prawnych konkretyzujących treść prawa własności czy określenie granic prawa własności, jak i faktyczne czynności organów państwa, mające za przedmiot dobra stanowiące własność jakiejś osoby. W zakresie rozróżnienia zakresów przedmiotowych art. 21 i 64 Konstytucji, Trybunał uznał, iż ,zasady ustrojowe, takie jak ta wyrażona w art. 21 Konstytucji RP, spełniają kluczowe znaczenie w perspektywie poszukiwania wzorca konstytucyjnego w zakresie dotyczącym badania konstytucyjności przepisów prawnych, o ile Konstytucja RP nie zawiera norm bardziej szczegółowych. W zakresie dotyczącym ochrony prawa własności oraz ograniczonych praw rzeczowych takie szczegółowe normy zawiera art. 64 Konstytucji. O ile art. 21 stwierdza jedynie, że «Rzeczpospolita chroni własność i prawo dziedziczenia», to art. 64 ust. 1 przyznaje każdemu «prawo do własności, innych praw majątkowych oraz prawo dziedziczenia»". ${ }^{18}$

Pojęcie własności najczęściej określane jest w oparciu o definicję negatywną wynikającą z art. 140 Kodeksu cywilnego. ${ }^{19}$ Norma ta zakłada, że w granicach określonych przez ustawy i zasady współżycia społecznego właściciel może, z wyłączeniem innych osób, korzystać z rzeczy zgodnie ze społeczno-gospodarczym przeznaczeniem swego prawa, w szczególności może pobierać pożytki i inne dochody z rzeczy. W tych samych granicach może rozporządzać rzeczą.

\section{Ograniczenie własności w świetle regulacji prawa niemieckiego i orzecznictwa hiszpańskiego}

Orzecznictwo sądów konstytucyjnych poszczególnych państw europejskich często odnosi się do właściwiej równowagi między interesem ogólnym a indywidualnym właściciela. W prawie niemieckim przyjmuje się podwójną naturę prawa

M. Bednarek, Mienie. Komentarz do art. 44-55 k.c., Kraków 1997, s. 28.

Orzeczenie Trybunału Konstytucyjnego z dnia 12 stycznia 1999 r., P. 2/98, OTK 1999, nr 1, poz. 2.

Ustawa z dnia 23 kwietnia 1964 r. - Kodeks cywilny, Dz.U. z 1964 r. Nr 16, poz. 93, ze zm. 
własności - z jednej strony realizuje się ją indywidualnie w swojej zasadzie, zaś socjalnie w zakresie korzystania z niej. Aspekt indywidualny i socjalny, w świetle tej koncepcji, wzajemnie się przenikają i wspólnie koegzystują. ${ }^{20}$

Koncepcja ta ma swoje odzwierciedlenie w art. 14 ust. 2 konstytucji niemieckiej, zgodnie z którym „Własność zobowiązuje. Korzystanie z niej winno zarazem służyć dobru ogółu". Jak podnosi S. Jarosz-Żukowska, adresatem tego nakazu (Sozialgebot) jest w pierwszej kolejności ustawodawca określający treść i granice prawa własności. Jest on zarówno uprawniony, jak i zobowiązany, by w kształtowaniu prawa własności respektować z jednej strony gwarancje tego prawa, z drugiej zaś jego społeczne obowiązki (Sozialpflichtigkeit). ${ }^{21}$

Odnosząc się do ograniczeń prawa własności w orzecznictwie hiszpańskim, należy zwrócić uwagę na tezę, w myśl której potrzeba indywidualna i społeczna funkcja prawa określają treść prawa własności niezależnie od rodzaju dobra, które jest jej przedmiotem, a prawo własności nie może być kwalifikowane wyłącznie jako prawo podmiotowe lub prawo indywidualne tej formule podporządkowane, lecz winno w tym samym stopniu uwzględniać nadaną mu funkcję społeczną. ${ }^{22}$ Stanowisko to wzbudziło kontrowersje, jako dopuszczające za daleką ingerencję w prawo własności, godzącą tym samym w istotę tego prawa, jako indywidualnego prawa podmiotowego, na rzecz społecznej jego funkcji. Jak podkreśla A. Łabno, granicą prawa własności jest owszem społeczna funkcja tego prawa, jednak każdorazowo należy mieć na uwadze jego istotę. ${ }^{23}$

\section{Przesłanki ograniczania prawa własności ze względu na ochronę środowiska w prawie polskim}

Ograniczenie prawa własności jest pojęciem wymagającym dookreślenia co do zakresu i rodzaju tego ograniczenia. Dla potrzeb niniejszego artykułu należy przyjąć definicję wypracowaną przez doktrynę prawa. Zgodnie z nią ograniczeniami takimi są „,wynikające z przepisów prawa (bezpośrednio lub z rozstrzygnięć władzy publicznej) uwarunkowania ograniczające treść lub sposób korzystania z własności, w tym nakładające określone obowiązki na właściciela wobec przedmiotu własności lub też zobowiązujące go do znoszenia określonego oddziaływania na przedmiot własności”. ${ }^{24}$

W pierwszej kolejności należy zastanowić się nad dopuszczalnym zakresem przedmiotowych ograniczeń. Za powszechny należy uznać pogląd, zgodnie z którym prawo własności nie jest współcześnie prawem absolutnym, nie podlegającym

S. Jarosz-Żukowska, Konstytucyjna zasada ochrony własności, Warszawa 2003, s. 132.

Ibidem, s. 134.

Ibidem, s. 135.

A. Łabno, Iberyjska droga do demokracji. Studium prawnokonstytucyjne, Warszawa 1996, s. 32.

J. Sommer, Ochrona środowiska a prawo własności, Wrocław 2000, s. 7. 
żadnym ograniczeniom. Podstawę tych ograniczeń nadaje już sama Konstytucja. Warto odnieść się w tym miejscu do wyroku Trybunału Konstytucyjnego, w którym podkreślono, że „pojmowanie prawa własności jako prawa absolutnego do rzeczy mogłoby się obrócić (...) w wielu wypadkach przeciwko samym właścicielom, jako że korzystanie z rzeczy w sposób nieograniczony prowadziłoby do naruszenia interesów innych właścicieli, a w konsekwencji do nie dających się pogodzić konfliktów. Takie pojmowanie własności mogłoby stać się podstawą wybujałego indywidualizmu i egoizmu, a w konsekwencji do samozniszczenia instytucji własności. ${ }^{25}$ Ponadto w orzecznictwie Trybunału dotyczącego ograniczeń prawa własności występuje odesłanie do innych regulacji konstytucyjnych, w tym do zasad sprawiedliwości społecznej, która zawiera w sobie zasadę dobra ogółu (interesu ogólnego). Tą ostatnią zasadę $\mathrm{w}$ połączeniu z zasadą demokratycznego państwa prawnego w ocenie Trybunału należy brać pod uwagę przy ustalaniu treści i zakresu ochrony prawa własności. ${ }^{26}$

Podstawę do ograniczenia prawa własności ze względu na ochronę środowiska można wyprowadzić już z samych zapisów ustawy zasadniczej. Jedną bowiem z przesłanek ograniczeń praw i wolności, a takim jest prawo własności, zgodnie $\mathrm{z}$ art. 31 ust. 3 Konstytucji RP, jest właśnie ochrona środowiska.

Ograniczeniem własności, które rysuje się w tym kontekście najwyraźniej, jest ograniczenie sposobu korzystania z nieruchomości w związku z ochroną zasobów środowiska, uregulowane w art. 130 p.o.ś. Przewidziano w nim trzy rodzaje ograniczeń, które mogą nastąpić przez:

- poddanie ochronie obszarów lub obiektów na podstawie przepisów ustawy o ochronie przyrody,

- ustalenie warunków korzystania z wód regionu wodnego lub zlewni oraz ustanowienie obszarów ochronnych zbiorników wód śródlądowych na podstawie przepisów ustawy - Prawo wodne,

- wyznaczenie obszarów cichych w aglomeracji oraz obszarów cichych poza aglomeracją.

Ze względu na najszerszy zasięg dokonywanych ograniczeń w zakresie prawa własności, należy odnieść się do poddania ochronie poszczególnych form ochrony przyrody, które niejednokrotnie są przyczyną ograniczeń prawa do korzystania z nieruchomości. Do form ochrony przyrody, w związku z którymi przewidziano możliwość ograniczenia prawa do korzystania z nieruchomości można zaliczyć:

- parki narodowe,

- rezerwaty przyrody,

- parki krajobrazowe, 
- obszary chronionego krajobrazu,

- pomniki przyrody, stanowiska dokumentacyjne, użytki ekologiczne, zespoły przyrodniczo-krajobrazowe.

Ponadto, co podkreśla A. Sommer, problematyka form szczególnej ochrony przyrody wiąże się ściśle z zagadnieniami zagospodarowania przestrzennego $\mathrm{w}$ tym szczególnie sensie, że przestrzenne formy ochrony przyrody muszą być wprowadzone do miejscowych planów zagospodarowania przestrzennego. Zazwyczaj wiąże się to $\mathrm{z}$ koniecznością zmiany dotychczasowego sposobu korzystania z nieruchomości, a tym samym w istocie stanowi zmianę jej wartości. ${ }^{27}$ Ograniczenia własności mogą następować właściwie przy wprowadzeniu każdej z form ochrony przyrody, zarówno w zakresie ochrony obszarowej, indywidualnej, jak i gatunkowej.

Przedmiotowy katalog ograniczeń nie wyłącza możliwości ograniczenia sposobu korzystania z nieruchomości w celu ochrony zasobów środowiska na podstawie przepisów ustawy o planowaniu i zagospodarowaniu przestrzennym. ${ }^{28}$

Ograniczenie takie wynikać może z miejscowego planu zagospodarowania przestrzennego, który obejmuje tereny podlegające ochronie ze względu na środowisko czy zasoby wodne. Ograniczenie sposobu korzystania z nieruchomości może również nastąpić w drodze decyzji ustalającej warunki zabudowy i zagospodarowania terenu. Jak podkreśla B. Rakoczy, należy zauważyć, iż problematyka zagospodarowania przestrzennego ogranicza prawo używania rzeczy. Właściciel ma bowiem możliwość tylko w takim zakresie korzystać ze swojej nieruchomości, w jakim przewidziane to jest $\mathrm{w}$ regulacji ustawowej, względnie w akcie prawa miejscowego. Należy w tym miejscu podkreślić, że jedną z wartości, której uwzględnienie jest konieczne podczas procesu planistycznego, jest właśnie ochrona środowiska. Powinna być ona w pierwszej kolejności uwzględniana w procesie planowania przestrzennego, jednak konieczne jest także jej zachowanie na etapie realizacji samego planu. ${ }^{29}$

Obszary ograniczonego użytkowania są kolejnym rodzajem ograniczenia sposobu korzystania $z$ nieruchomości. Ustanawiane są na podstawie art. 135 p.o.ś. W związku z brakiem definicji ustawowej, w doktrynie przyjmuje się, że „chodzi o obszary objęte ograniczeniami w sposobie korzystania z nieruchomości, wprowadzonymi $\mathrm{w}$ drodze przepisów prawa miejscowego ze względu na wymagania ochrony zasobów środowiska". ${ }^{30}$ Zgodnie z linią orzeczniczą, uznaje się, że obszar ograniczonego użytkowania w zasadzie jest wyznaczany dla obszaru, na którym doszło do przekroczenia określonych norm, a obszar oddziaływania obiektu to także teren, gdzie uciążliwości związane z przedsięwzięciem mieszczą się w gra-

$27 \quad$ Ibidem, s. 32.

28 Ustawa z dnia 27 marca 2003 r. o planowaniu i zagospodarowaniu przestrzennym (Dz.U. z 2003 r. Nr 80, poz. 717 ze zm.).

29 B. Rakoczy, Ograniczenia..., op. cit., s. 286.

30 J. Rotko, Komentarz do ustawy - Prawo ochrony środowiska - ochrona zasobów środowiska, tyt. II, Wrocław 2002, s. 144. 
nicach norm określonych przez przepisy prawa lub wydane na ich podstawie decyzje. Także zachowanie odległości przewidzianych przepisami technicznymi nie przesądza o braku oddziaływania obiektu poza obszarem nieruchomości inwestora. ${ }^{31}$ Zdaniem K. Gruszeckiego, należy uznać, że ,jedną z podstawowych przesłanek uzasadniających ustanowienie obszaru ograniczonego użytkowania jest wystąpienie szkodliwego oddziaływania wywołanego przekroczeniem dopuszczalnych norm immisyjnych." 32

Przesłanki ograniczeń sposobu korzystania z nieruchomości poprzez ustanowienie obszarów ograniczonego użytkowania przewiduje art. 135 p.o.ś. Jeżeli z przeglądu ekologicznego albo z oceny oddziaływania przedsięwzięcia na środowisko, albo z analizy porealizacyjnej wynika, że mimo zastosowania dostępnych rozwiązań technicznych, technologicznych i organizacyjnych nie mogą być dotrzymane standardy jakości środowiska poza terenem zakładu lub innego obiektu, to dla oczyszczalni ścieków, składowiska odpadów komunalnych, kompostowni, trasy komunikacyjnej, lotniska, linii i stacji elektroenergetycznej oraz instalacji radiokomunikacyjnej, radionawigacyjnej i radiolokacyjnej tworzy się obszar ograniczonego użytkowania.

Ustawodawca przewidział także możliwość utworzenia strefy przemysłowej, gdzie standardy jakości środowiska ulegają znacznemu przekroczeniu. Zgodnie $\mathrm{z}$ art. 136a p.o.ś. na obszarach określonych w miejscowym planie zagospodarowania przestrzennego jako tereny przeznaczone do działalności produkcyjnej, składowania oraz magazynowania i równocześnie użytkowanych zgodnie z przeznaczeniem może być utworzona strefa przemysłowa. Strefa taka tworzona jest bądź na wniosek zainteresowanego podmiotu, bądź na wniosek władającego powierzchnią ziemi, na terenach, które mają być objęte strefą przemysłową. W pierwszym przypadku wnioskodawca musi uzyskać pisemną zgodę wszystkich podmiotów władających powierzchnią ziemi. Wyrażenie takiej zgody wyłącza roszczenia o ewentualny wykup nieruchomości lub odszkodowanie, bowiem tylko brak zgody w przypadku objęcia powierzchni ziemi strefą przemysłową jest przesłanką umożliwiającą dochodzenie tych roszczeń. Nie ulega więc wątpliwościom, że utworzenie strefy przemysłowej z pewnością wpływa na wykonywanie prawa własności nieruchomości, poddając je ograniczeniom.

\section{Odszkodowanie jako element zachowania równowagi}

Instrumentem służącym rekompensacie za ograniczenia własności jest odszkodowanie. Jako że temat ten pozostaje poza zakresem niniejszego opracowania, należy się w tym obszarze jedynie odwołać do przepisów materialnoprawnych usta- 
nawiających dane ograniczenia. Kwestie odszkodowawcze związane z ograniczeniem prawa własności ze względu na ochronę środowiska regulowane są w dziale IX p.o.ś. Artykuł 129 p.o.ś. stanowi, że jeżeli w związku z ograniczeniem sposobu korzystania z nieruchomości, korzystanie z niej lub z jej części w dotychczasowy sposób lub zgodny z dotychczasowym przeznaczeniem stało się niemożliwe lub istotnie ograniczone, właściciel nieruchomości może żądać wykupienia nieruchomości lub jej części. Odszkodowanie przysługuje także w związku ze szkodą wynikłą z ograniczenia w dotychczasowym sposobie korzystania z nieruchomości. Obejmuje ona także zmniejszenie wartości nieruchomości. Roszczenie odszkodowawcze przysługuje nie tylko właścicielowi, ale także użytkownikowi wieczystemu nieruchomości, a w przypadku ograniczenia praw rzeczowych na nieruchomości, także osobie, której przysługuje takie prawo. Z roszczeniem tym można wystąpić w okresie 2 lat od dnia wejścia w życie rozporządzenia lub aktu prawa miejscowego powodującego ograniczenie sposobu korzystania z nieruchomości. Jednocześnie ustawodawca wyłączył możliwość dochodzenia odszkodowania z tytułu ograniczeń sposobu korzystania z nieruchomości na podstawie ustawy o planowaniu i zagospodarowaniu przestrzennym. W związku z faktem, iż przysługujący na podstawie tej drugiej regulacji termin wystąpienia z roszczeniem odszkodowawczym jest dłuższy, wyłączenie to jest często krytykowane w doktrynie.

\section{Podsumowanie}

Relacja pomiędzy prawem własności a ochroną środowiska jest zagadnieniem wielowymiarowym. Z jednej strony należy ustalić zakres dopuszczalnych ograniczeń ustawowych prawa własności ze względu na ochronę środowiska, z drugiej należy wyważyć interes publiczny i prywatny, kierując się zasadą zrównoważonego rozwoju. Nie można uznać, odwołując się do konstytucyjnej ochrony własności, że ochrona ta jest bezwzględna, bowiem częstokroć doznaje ona ograniczeń na rzecz ochrony środowiska. Jak trafnie ujął to J. Sommer, własność zawsze powinna być realizowana z uwzględnieniem jej społecznego-gospodarczego przeznaczenia, co zawiera w sobie również konieczności wynikające $\mathrm{z}$ potrzeb ochrony środowiska. Własność podlega także ograniczeniu wskutek działań ustawodawcy dążącego do realizacji określonych interesów publicznych. ${ }^{33}$ B. Rakoczy uznaje, że ograniczenie prawa własności ze względu na ochronę środowiska spełnia przesłankę konieczności, bowiem ustawodawca wprowadza tylko regulacje konieczne ze względu na ochronę środowiska. Jego zdaniem, nie ma innego sposobu ochrony środowiska, jeśli nie poprzez ingerencję w prawo własności. ${ }^{34}$

33 J. Sommer, Ochrona..., op. cit., s. 28.

34 B. Rakoczy, Ograniczanie..., op. cit., s. 316. 
W odniesieniu do sformułowanego w Konstytucji RP postulatu zachowania zrównoważonego rozwoju, należy uznać, iż w kontekście ograniczenia własności ze względu na ochronę środowiska winien on być realizowany poprzez ważenie interesu publicznego i prywatnego. Niejednokrotnie wiązać się to będzie z daleko idącymi ograniczeniami sposobu korzystania przez właściciela z jego nieruchomości. Przy uwzględnieniu zasady zrównoważonego rozwoju, istniejący konflikt pomiędzy interesem prywatnym jednostki a potrzebami całej ludzkości rysuje się szczególnie wyraźnie. To właśnie owa zasada warunkuje ograniczanie potrzeb indywidualnych dla dobra społeczeństwa, a zatem stanowi element ograniczający prawa i wolności jednostki. Należy jednak zwrócić uwagę na fakt, iż w idei zrównoważonego rozwoju pośrednio mieści się założenie, w którym bieżące ograniczanie praw i wolności jednostki następuje w imię dobra wspólnego, wymiernej korzyści w postaci prawidłowo funkcjonującego środowiska. 
OWNERSHIP REDUCTION FOR THE PROTECTION OF THE ENVIRONMENT IN THE CONTEXT OF SUSTAINABLE DEVELOPMENT

The article deals with the issues of ownership reduction for the protection of the environment in the context of sustainable development. To identify the subject, the publication discusses the different concepts of ownership as well as the concept of sustainable development. Next, reference is made to ways to reduce property rights in connection with the protection of the environment on the examples of Germany and Spain. Subsequently, evidence of ownership restrictions for the protection of the environment are presented against the backdrop of Polish legal regulations. Ultimately, reference is made to compensation as an instrument of restitution for restrictions on ownership.

Keywords: environmental protection, ownership, limiting ownership, sustainable development, compensation, industrial zones of limited use 